【論 文】

UDC : 72.03(52): $694: 69.007 .2$
日本建筑学会計画系論文報告集 第 411 号・1990 年 5 月

Journal of Archit. Plann. Environ. Engng, AIJ, No.411, May, 1990

\title{
近江国における郡別大工組の存続と分立について A STUDY OF THE COUNTY CARPENTER PARTIES IN EAST OMI-COUNTRY
}

\author{
吉田高子* \\ Takako YOSHIDA
}

\begin{abstract}
This paper is a part of my study on the carpenter parties Omi-Country during the Edo era.
In the east of the Omi-Country, there were five different carpenter parties : Kanzaki, Gamo, Yasu, Kurita and Koga county party.

These county parties were different on some points, such as the number of the carpenter in the party, the sphere of their influence in the county area, and how much they prospered.

Under these conditions, the management pattern of the parties was transformed into the three types : of-county party type (kanzakigun-party and Yasugun-party), county neighbourhood party type (Gamogun-Party) andin-county party type (Kuritagun-Party was divided into kuritakita-party and kuritaminami-party. Kogagun-party was divided into Bodaiji-party, Yamakita-party, Yamaminami-party, Kashiwagi-party and Soma-party).
\end{abstract}

Keywords : carpenter, Omi-County, County-party, transformation

\section{1.はじめに}

中井役所支配六箇国大工組の内，河内国の大工組につ いては先に報告した通りりで，河州六組は郡域を越えて 広域に組域を持つ「広域大工組」の形態をとる 3 組と， 最寄り数ヶ村の集合で狭域支配の「向寄大工組」 3 組が 並存する状況であった。

広域大工組の存続には，河内国古橋組では世襲組頭家 の存続と共に向寄による組内構成，向寄年行事による組 内大工支配等が寄与したことを明らかにした。

近江国の大工組については，組数の上から見ても明和 2 年 (1765) に 26 組（大津 6 組，在方 20 組), 安政 2 年 (1855) には 43 組（大津 6 組，在方 37 組）と多数で あり，河内国大工組とは組形態を異にしていたことが想 像されこの内，東近江の甲賀郡組については 1 郡をもっ て仕事範囲とする「郡別大工組」の存在が知られてい る2!。の郡別大工組については, 安政 2 年当時の六䇢 国大工組の中でも大工組名または大工組グループ名に郡 名を冠しているのは，大和国宇陀組 1 組を除くと近江国 以外には存在せず，近江国に特徴的に見られるものであ ることが考えられる。

そこで，近江国の大工組の形態について概観し，次に 郡別大工組の存在が確認される東近江五郡（神崎・蒲 生・野洲・栗太・甲賀郡）の大工組の構成形態，更にそ の存続と分立についで3)，主に各組頭家所蔵の大工組関 係文書 ${ }^{4} に よ り$ 明らかにしようとするものである。

* 近畿大学 講師・工博

\section{2. 近江国に於ける郡別大工組の地域分布}

明和 2 年（推定）の「六ヶ国大工杣木引組頭名前并人 数書 $\left.{ }^{5}\right\rfloor 亡$ 安政 2 年『御造営御用役六䇢国三職与頭名 ${ }^{61}$ によって，郡別大工組の近江国における所在状況をみる ことにする。表一1 はこの史料によって明和 2 年と安政 2 年の近江国の大工組名と組頭居住地を示したものであ り，図一1は安政 2 年の組頭居住地を地図上に取ったも のであるが，通常この組頭居住地は組所在地と考えて良 い。

この内大津六組は京や大阪の都市大工組と同様，大工 職を専業とする町大工を構成員としているもので，いず れも大津に所在する町大工組で, ここに郡単位の大工組 は存在しない。

在方大工組については琵琶湖西岸の西近江二郡，つま り高島郡と滋賀郡には郡別大工組は存在しなかった。こ の地域では寛永 13 年（1636）に既に大工頭の存在が確

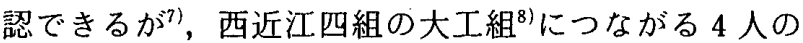
大工頭は，何れも高島郡内の安鼻川が琵琶湖に流入する 河口周辺地域に居住していた。西近江四組は，このあた りに向寄大工組を構成していたと言えるが，高島郡横江 村居住の組頭中西佐右衛門は横江村周辺大工に加え，大 津を除く滋賀郡全域の大工をも支配していたから，四組 のうち横江組のみは広域大工組であった。

東近江五郡（琵琶湖東岸の神猗・蒲生・野洲・栗太・ 甲賀郡）では，寛永期には郡毎に大工頭が一人ずつ存在 Lecturer of Kinki Univ., Dr. Eng. 
表一1＼cjkstart近江国の大工組頭居住地と大工人数

\begin{tabular}{|c|c|c|c|c|c|c|c|c|c|}
\hline \multicolumn{3}{|c|}{ 安政 2 年 (1855) } & 近江四十三組 & \multicolumn{2}{|c|}{ 家大工人数 2104 人 } & \multicolumn{2}{|c|}{ 明和 2 年 (1765) } & \multicolumn{2}{|c|}{$\begin{array}{lr}\text { 大津大工六組 } & 113 \text { 人 } \\
\text { 在方大工侙拾組 } 1011 \text { 人 }\end{array}$} \\
\hline \multicolumn{2}{|c|}{ 番号 } & 組グループ名 & 大工組名 & 組頭居住地 & 大工人数 & 大工組名 & 組頭居住地 & \multicolumn{2}{|c|}{ 大工人数 (内引高持) } \\
\hline 大 & $\begin{array}{l}1 \\
2 \\
3 \\
4 \\
5 \\
6\end{array}$ & 近江大津六組 & $\begin{array}{l}\text { (百石丁組) } \\
\text { 船丁組 } \\
\text { 八丁組 } \\
\text { 小王丁組 } \\
\text { (石橾組) } \\
\text { 松本組 }\end{array}$ & \begin{tabular}{|} 
大津百石町 \\
船 \\
帛石町 \\
板䙓丁 \\
石橋町 \\
小川町
\end{tabular} & 210 人 & $\begin{array}{l}\text { 百石町組 } \\
\text { 船町組 } \\
\text { 八町組 } \\
\text { 小王町組 } \\
\text { 石橋町組 } \\
\text { 松本組 }\end{array}$ & $\begin{array}{l}\text { 大津 } \\
\text { 大津 } \\
\text { 大津 } \\
\text { 大津 } \\
\text { 大津 } \\
\text { 大津 }\end{array}$ & $\begin{array}{l}20 \hat{\text { 人 }} \\
19 \hat{\jmath} \\
17 \hat{人} \\
19 \hat{人} \\
18 \hat{人} \\
20 \hat{人}\end{array}$ & \\
\hline 䠓 & $\begin{array}{r}7 \\
8 \\
9 \\
10 \\
11 \\
12 \\
13 \\
14\end{array}$ & $\begin{array}{r}\text { 江州滋賀郡 } \\
\text { 高島郡 }\end{array}$ & 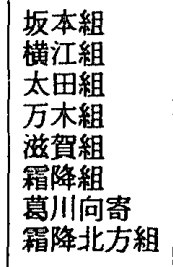 & 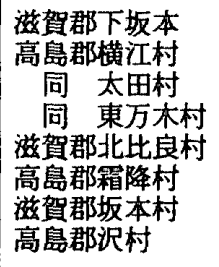 & 351 人 & $\begin{array}{l}\text { ( 横江組) } \\
\text { ( 太田組) } \\
\text { 万木組 } \\
(\text { 箱降組 })\end{array}$ & $\begin{array}{l}\text { 同左 } \\
\text { 同左 } \\
\text { 高島郡西万木村 } \\
\text { 同左 }\end{array}$ & $\begin{array}{l}112 \text { 人 } \\
48 \text { 人 } \\
52 \text { 人 } \\
47 \text { 人 }\end{array}$ & $\begin{array}{l}\text { 内78人 } \\
\text { 内23人 } \\
\text { ( 持高构) } \\
\text { ( 持高有) }\end{array}$ \\
\hline \multirow{5}{*}{\begin{tabular}{|l} 
東 \\
近 \\
江 \\
吾 \\
郡
\end{tabular}} & $\begin{array}{l}15 \\
16\end{array}$ & 栗太郡組 & 南組 & $\begin{array}{l}\text { 栗太郡矢橋村 } \\
\text { 同 マカリ村 }\end{array}$ & 230 人 & $\begin{array}{l}\text { 南組 } \\
\text { 北組 }\end{array}$ & $\begin{array}{l}\text { 同左 } \\
\text { 栗太郡繶村 }\end{array}$ & 29 人 & 内25人 \\
\hline & 17 & 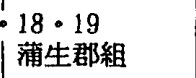 & 蒲生郡組 & $\begin{array}{l}\text { 蒲生郡竹村他 } \\
\text { 組頭8 人 }\end{array}$ & 512 人 & \multicolumn{2}{|c|}{ （蒲生郡組）蒲生郡八幡 } & & （ 持高伨） \\
\hline & $\begin{array}{l}20 \\
21 \\
22 \\
23 \\
24\end{array}$ & 甲賀郡組 & $\begin{array}{l}\text { 菩提寺南組 } \\
\text { 組 } \\
\text { 山北組 } \\
\text { 杣之庄組 } \\
\text { 山南組 }\end{array}$ & $\begin{array}{l}\text { 甲驾郡 } \\
\text { 同林口村 } \\
\text { 同隠岐村 } \\
\text { 同深川村 } \\
\text { 同池田村 }\end{array}$ & 255 人 & \multirow{3}{*}{$\begin{array}{l}\text { 菩提寺組 } \\
\text { 組 } \\
\text { 山北組 } \\
\text { 杣組 } \\
\text { 山南組 } \\
\text { ( 野洲組) } \\
\text { 佐生組 }\end{array}$} & $\begin{array}{l}\text { ）甲賀郡市場村 } \\
\text { 甲賀郡潼村 }\end{array}$ & $\begin{array}{l}87 \text { 人 } \\
30 \text { 人 }\end{array}$ & $\begin{array}{l}\text { 内11人 } \\
\text { (持高有) } \\
\text { 内 } 18 \text { 人 }\end{array}$ \\
\hline & 25 & 野洲組 & 野洲組 & 野洲郡木浜村 & 122 人 & & \multirow{2}{*}{$\begin{array}{l}\text { 野洲郡吉地 } \\
\text { 神崎郡佐生村 }\end{array}$} & 63 人 & 内25人大I \\
\hline & 26 & 神崎郡組 & 神崎郡組 & 神畸郡能登川村 & & & & 27 人 & \\
\hline \multirow{3}{*}{$\begin{array}{l}\text { 琵 } \\
\text { 琵 } \\
\text { 湖 } \\
\text { 東 } \\
\text { 北 } \\
\text { 地 } \\
\text { 域 }\end{array}$} & & & & & & \multirow{3}{*}{$\begin{array}{l}\text { 的原組 } \\
\text { 能登瀬組 } \\
\text { ( 同左 }) \\
\text { ( 上野組) } \\
\text { ( 高田組) }\end{array}$} & \multirow[b]{2}{*}{$\begin{array}{l}\text { 坂田郡柏原宿 } \\
\text { 同 左 } \\
\text { 同左 (十六ヶ村) } \\
\text { 同 左 }\end{array}$} & \multirow[b]{2}{*}{17 人 } & \\
\hline & $\begin{array}{l}28 \\
29 \\
30 \\
31 \\
32\end{array}$ & 坂田郡組 & $\begin{array}{l}\text { 柏原組 } \\
\text { 能登瀬組 } \\
\text { 横山組 } \\
\text { 十六ケ村組 } \\
\text { 上野組 } \\
\end{array}$ & $\begin{array}{l}\text { 坂田郡柏原駅 } \\
\text { 同 能登瀬村 } \\
\text { 同 本庄村 } \\
\text { 同 多和田村 } \\
\text { 同 上野村 }\end{array}$ & 92 人 & & & & \\
\hline & $\begin{array}{l}33 \\
36 \\
37 \\
38 \\
39 \\
40 \\
41\end{array}$ & $\begin{array}{l}34 \cdot 35 \\
\text { 浅井郡組 } \\
\text { 尹香郡組 }\end{array}$ & $\begin{array}{l}\text { 上浅井組 } \\
\text { 中浅井組 } \\
\text { 下浅井組 } \\
\text { 東浅井組 } \\
\text { 西浦組 } \\
\text { (富田組) } \\
\text { 大北組 }\end{array}$ & 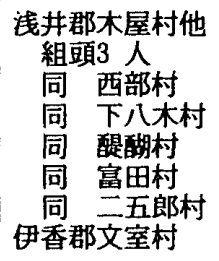 & 218 人 & & $\begin{array}{l}\text { 线井郡留田村 } \\
\text { 田香郡権寺村 } \\
\text { 尹香郡井口村 }\end{array}$ & $\begin{array}{r}19 \text { 人 } \\
25 \hat{\curlywedge} \\
9 \text { 人 }\end{array}$ & （持高有） \\
\hline
\end{tabular}

他に、42（石山組 栗太郡） 43 （草津組 栗太郡） 番号は図一に同じ

安政 2 年: 「御造営御用役六固国三職組頭名」による。但し（）の 組名は「新造内褧御造営棟梁方雑記全」で補足した。 * 大工人数は「安政度京都御所造営時の各大工組の構成人員」西 和夫・渡辺腃による。
明和 2 年：「六ヶ国大工杣木婏組頭名前并人数書」 による。但し（）の組名は推定
しており ，郡内居住大工はその大王頭の配下にあると 言う郡別大工組を構成していた様子が窥える。更に安政 2 年においても表一1に見るように，栗太郡組と甲賀郡 組では組グループ名として郡組の名を残しており，蒲生 郡組・神崎郡組・野洲組は郡単位の大工組を構成してい る。このように東近江五郡については，寛永期から安政 2 年に至る史料により, 郡別大工組の存在を指摘するこ とができる。

一方, 琵琶湖東北の四郡（犬上郡を除く 4 郡で愛智・ 坂田・浅井・伊香郡）については安政 2 年には組グルー
プ名として郡組名を持つものの, 組名としての郡組名を とっていない。これら四郡には彦根領村が多く存在した が, 彦根領内居住大工は遅くとも寛永 13 年に流, 中丰 配下から除かれており，井伊家の支配を受けていた10)。 そのため, 各郡における中井家支配下大工は, 颜根領村 を除く地に限られ（これが後に郡内の各地に向等大工組 を構成することになったものと考えられる）中非支配の 大工高も少ない111)。これは江戸初期において, 中井家の 要請でこれら四郡が作事等に出動することの少なかった ことを示している。 


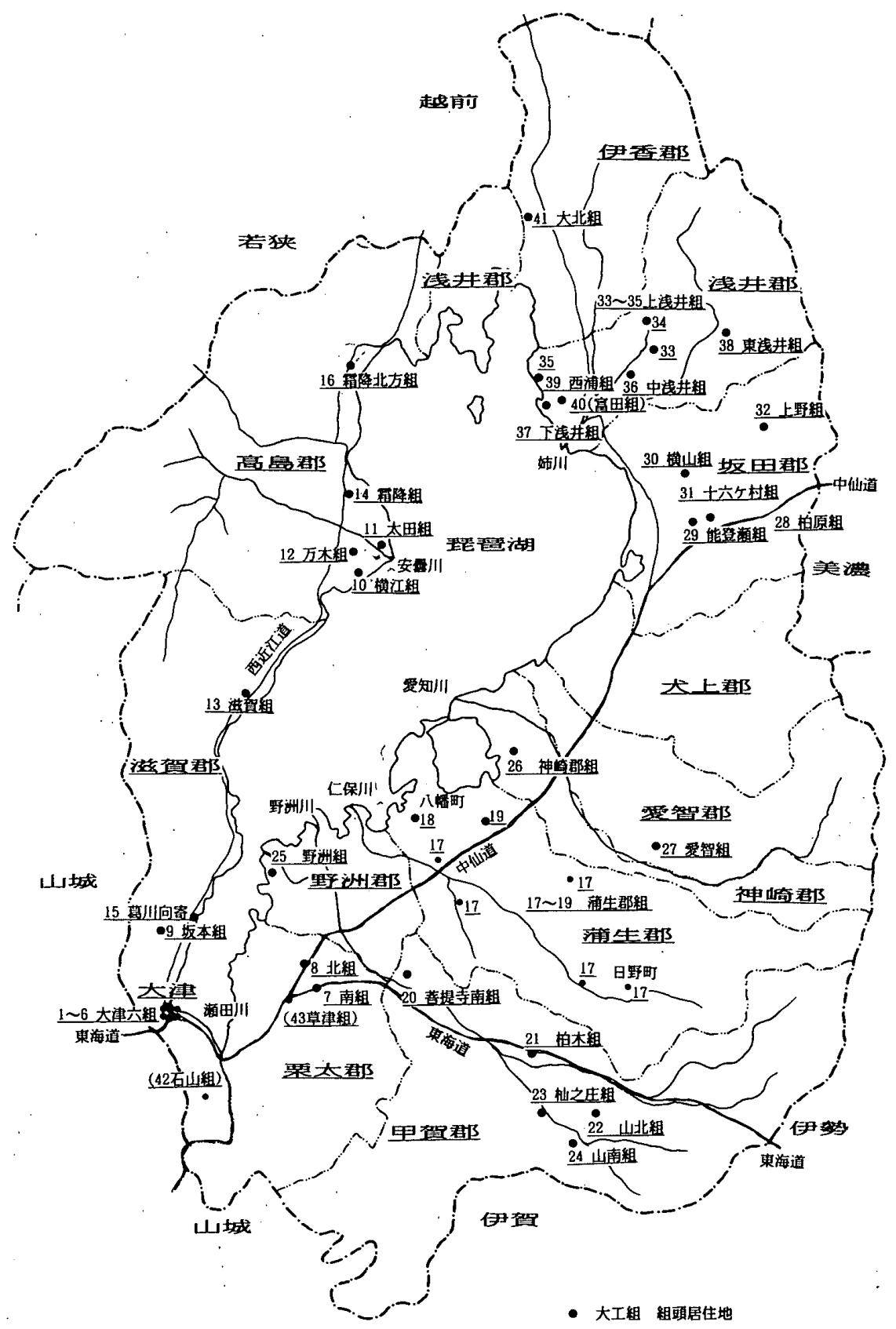

图一1 安政 2 年の近江国における大工組頭居住地
印があるが，それ以前の史料も欠い ており; 向寄大工組の集合として郡 別大工組の呼称が用いられたもので あり，郡域を組域とする郡別大工組 ではかったといえる。

伊香郡については寛永 18 年に組 頭権平の名がみられ, 明和 2 年にも 2 人, 安政 2 年に 1 人の組頭がいる が, 郡別大工組としての存在は史料 上確かめられない。

以上のように郡別大工組は, 近江 国においても東近江五郡に限り存在 した大工組の形態であったというこ とができよう。

\section{3. 郡別大工組の成立と存在形態}

1) 東近江五郡大工組の成立

東近江において郡別に大工頭が記 された最も早いものは，慶長 16 年 (1611) 亥.12月の八幡大工所をめ ぐる相論に関する高木家文書で，こ れには各郡を代表するような形で蒲 生郡作右工門, 神崎郡兵太夫, 栗本 郡三右エ門の名が見られる。この名 は寛永 13 年 (1635) 11月「近江国 大工石高之帳」に記された「近江国 大工頭蒲生郡 作右工門, 栗本三右 工門, 甲賀佐治右工門, 神崎兵左工 門」の 4 郡の大工頭名に繁がるもの である。つまり東近江五郡には，組 形成以前から有力な大工が大工頭と して各郡に存在しており, 京の中井 家は江戸初期の御用作事等に彼ら大 工頭を通じて多数の大工を召集して いだは。

また東近江五郡は，東海道・中仙
この四郡の内, 愛智郡には中井配下の大工高もなく, 郡別大工組は存在しなかったとして良いが，坂田郡につ いては寛永 18 年に組頭九右工門の名が見られ，能登瀬 村組頭九左衛門の存在が宝暦 7 年 (1757) の坂田郡上野 村の松井家文書により確かめられる。しかし, 明和 2 年 の組大工人数は 6 人と少なく, 能登瀬組頭九左衛門の支 配は能登瀬村を中心としたもので，同じ坂田郡に存在す る柏原組, 十六ヶ村組, 上野村組と同様, 向寄大工組の 形態をとっていた考えられる。

浅井郡には竹生島御宮大工の阿部権正の他に, 富田村 組頭西島但島が明和 2 年が見られる。また文化 13 年の 『大工仲間定書』 ${ }^{121}$ には,「郡中立会い相論之上相究如 候上者」とあり郡内の 5 組の組頭と竹生島御宮大工の連
道で江戸に通じ京に近いと言う交通上便利な地にあり， そのような衔用作事等の場合 ${ }^{(4)} に$ ，大工頭を通じて郡内 の大工を質・人数等の上で揃え易く $\left.{ }^{15}\right)$ 中井家にとって東 近江五郡大工は, 都合の良い存在であり, 都合のよい形 態を持っていたといえる。

これは江戸初期の御用作事などの際に, 中井家がその 出身地である大和国平群郡の法隆寺村とその周辺地域の 大工を集中的に召集したことが，ここに多くの向寄大工 組を構成させた ${ }^{(6)}$ と同じで, 東近江五郡の大工を各郡の 大工頭を通じて召集したことが，東近江五郡に郡別大工 組を形成させることに紫がったものと考えられる。

また，寛永 18 年（1641）の『和州平群之郡東林寺奉 加帳』に 
表一2 東近江の大工組関係文書。

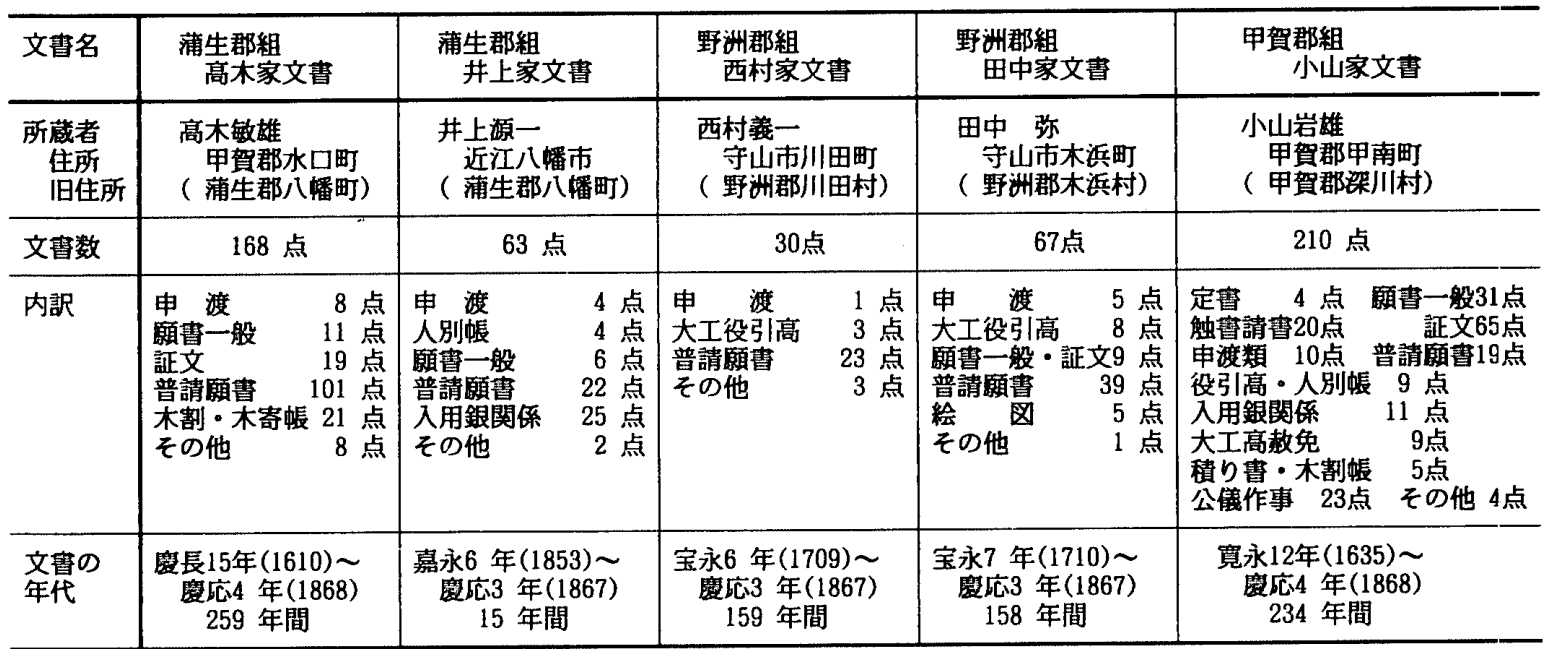

江州作右工門 (蒲生郡) 同組三人

江州かもう長兵へ(蒲生郡) 同組二十六人

江州三右工門 (栗太郡) 同組三十九人

江州やす藤左工門 (野洲郡) 同組二十四人

江州兵左工門（神猗郡）同組二十四人

江州佐次右工門 （甲賀郡）同組二十七人

（）内は推定

の記載が見られる。つまり，寛永 18 年には郡別に大工 頭（但し，蒲生郡では作右エ門と長兵衛 2 人）の下に大 工組の成立していたことがわかる。

郡別大工組の組域に関しても, 稿本高木家文書寛文 8 年 (1668)『蒲生郡大工人数書帳』の前書に「一, 他郡 江出入致間敷事」の一項が見られるところから，同年に は五郡大工組に郡別の意識が確立していたことがわか る。

\section{2) 東近江五郡大工組の存在状況}

次に表一2に示した組頭家所蔵文書等によって東近江 五郡の郡別大工組の存在状況を見ることにする。表一3 に示したように東近江五郡においては享保 20 年 (1735) 頃まではこの郡別大工組の形態が五郡共に存続してい た。それは元文 5 年 (1740) の小山家文書に

\section{為取替証文之事}

一, 東近江五郡之儀者 先年より郡切二細工仕候事五郡之組 頭并組中立会 互二急度申合其旨守来り候處に此度不届キ之 儀御座候二付 又々五郡之組頭立会相談之上 相改弥々古来 之通可相守之旨 相対相済証文為取替申候 然ル上八以後他 郡二入込細工仕候儀堅仕間舗候 向後此旨不相守他郡入入込 其郡之組頭へ不遂相対 猥二細工仕候者在之候八〉御上へ 御断申急度曲事之御願可申上候 為後日取替証文仍而如件 元文五年庚申三月五日

\begin{tabular}{llll} 
栗太郡大工組頭 & \multicolumn{1}{c}{ 穴村 } & 與惣右衛門 & 印 \\
甲賀郡大工年寄㥎代 & 泉村 & 太兵衛 & 印 \\
野洲郡大工組頭 & 永原村 & 喜右衛門 & 印 \\
蒲生郡大工組頭 & 八幡町 & 但馬 & 印 \\
神崎郡大工組頭 & 伊庭村 & 太郎右衛門 & 印
\end{tabular}

とあるように，栗太・甲賀・野洲・蒲生・神崎の 5 郡で は(1)古来の通り郡切に細工をすること(2)他郡に入って細
工をしないこと(3)他郡に入込む場合はその郡の組頭の許 可を得ること，等を申合わせており，郡別大工組を保っ ていたことが判る。

3）東近江五郡大工組の支配範囲

五郡大工組の支配範囲は，いずれも郡域を組の支配範 囲とするものであるが, 各郡の広さや地理的条件は大き く異なっていた。(図一2)

まず神崎郡（現，神崎郡と八日市市北部）については 愛智川に沿って，その南側に東西に細長く延びた形と なっているが，郡域は狭く村落は西部に集まっている。

さらに神崎郡には先に述べたように井伊支配の廦根領の 54 ケ村が散在しており，神崎郡組の支配範囲はそれほ ど大きいものではなかった。

蒲生郡（現, 蒲生郡，近江八幡市，八日市市南部）は 広い郡域を有し，郡内には中央を東西に流れる日野川の 上流に日野町, 琵琶湖側に八幡町という商業の栄えた二 つの在郷町が存在していた。この広域を支配するために 蒲生郡組内は, 琵琶湖に近い八幡町を含む下向笴, 日野 川中流の鵜川周辺の中向寄, それに日野町を含九日野向 寄の大きく三向寄に分けられていた ${ }^{17)}$ 。

野洲郡 (現，野洲郡，守山市) は野洲川下流(琵琶湖 岸の狭くまとまった郡であり，野洲郡大工組の支配域も 他組に比べ狭かったことがわかる。

栗太郡（現，草津市，栗太郡，大津市東南部）は野洲 郡の 3 倍に近い広さを有するが，東部は山間地带である ため大工も琵琶湖沿岸の北西部に多く居住していたと栲 えられる。また栗太郡組大工は地理的には陸路，水路共 に京に最も近い所に住んでいたことになる。

甲賀郡組の支配範囲である甲賀郡（現，甲賀郡）は広 大な郡域となっているが, 東西に野洲川上流の横田川之 東海道が通り，南部の山間部を除き郡組内の交通の便は 良かったことがわかる。

\section{4. 東近江五郡の郡別大工組の存続と分立}

1)五郡大工組の変遷と組人数 


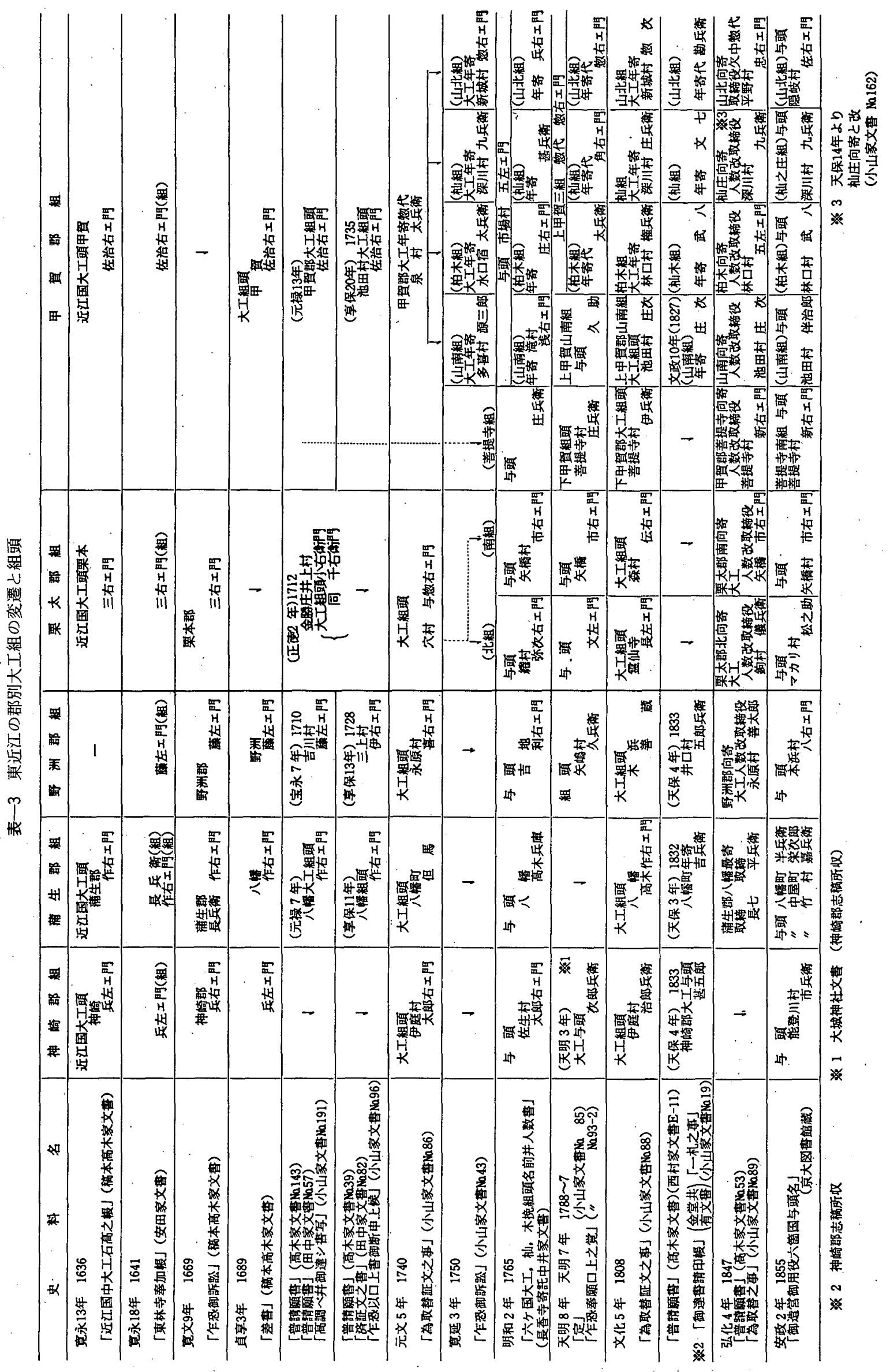


表一3は郡別に大工組と組頭の変遷状況を見たもので ある。郡別大工組の世襲の組頭は, 神崎郡組兵左工門, 蒲生郡組高木作右工門, 野洲郡組藤左工門, 栗太郡組三 右エ門，甲賀郡組佐治右エ門であった。

この内, 神崎郡組兵左工門については資料を欠いてお り詳しいことはわからないが, 栗太郡組三右工門は正徳 2 年 (1712) 以前に ${ }^{18)}$, 野洲郡組藤左工門は宝永 7 年 (1710), 甲賀郡組佐治右工門は享保 20 年 (1735) を最 後として退去しているのに対し，蒲生郡組高木作右工門 は文化 5 年 (1808) までは組頭を続けていたことがわか る。

明和 2 年 (1765) の大工組と組頭の状況を組別に見る と表一1，3のようになる。つまり，神崎郡組の組頭は 佐生村太郎右エ門になっており，組人数は 27 人と少な いが, 内 17 人は大工役引高をもつ引高持大工であり, 組内における特権大工の多さと江戸初期からの大工家の 存在を示している。

蒲生郡組は, 組頭高木兵庫 (作右エ門) の下に 324 人 もの大工が存在していた。これは六箇国大工組の中でも 京二十組中の木子組 358 人に次ぐ多人数大工組であっ た。蒲生郡は組域内に八幡町や日野町といった当時繁栄 を誇った町を抱えており，その商業活動が建築生産需要 を生み大工人数の増加に繋がったものと考えられる。

野洲郡組の組頭は吉地村利右工門で組人数は 63 人で あった。この内 25 人は引高持大工である。また 5 人は 引高持で大工職を辞めている。

栗太郡組は北組と南組の 2 組に分立している。北組の 組頭は繚村弥治右工門で 72 人の組大工がいたが, 北組 は以後の組頭居住地から見て草津川以北を組域としたの ではないかと考えられる。南組の組頭は矢橋村市右工門 で安政 2 年 (1855) に至るまで代々南組の組頭を勤めた ようである。明和 2 年の組大工人数は 29 人であるが, この内 25 人が引高持であり, 保守的権力の強い大工組 であったと考えられる。

甲賀郡組も明和 2 年には菩提寺組と山南組, 柏木組, 山北組, 杣組の 5 組に分立している。しかし, 組頭は変 則的であり，菩提寺組の庄兵衛と残る 4 組の組頭として 市場村五左工門の計 2 人しかいない。

甲賀郡の 5 組の組人数については菩提寺組 16 人, 山 南組 30 人,柏木組・山北組・杣組は 3 組で 87 人であり, これらの内, 引高持は菩提寺組・山南組あわせて 29 人 となっている。

また, 文化 5 年の五郡大工組の状況については, 小山 家文書によって知ることができる。つまり

\section{為取替証文之事}

一 東近江五郡之儀者先年より郡限二細工仕筈二五郡組頭立 会申合候処 年久敷能成候二付五郡之内甲賀栗本神崎三郡者 古証文粉失二付 此度蒲生野洲二郡之以先例を三郡共相改申

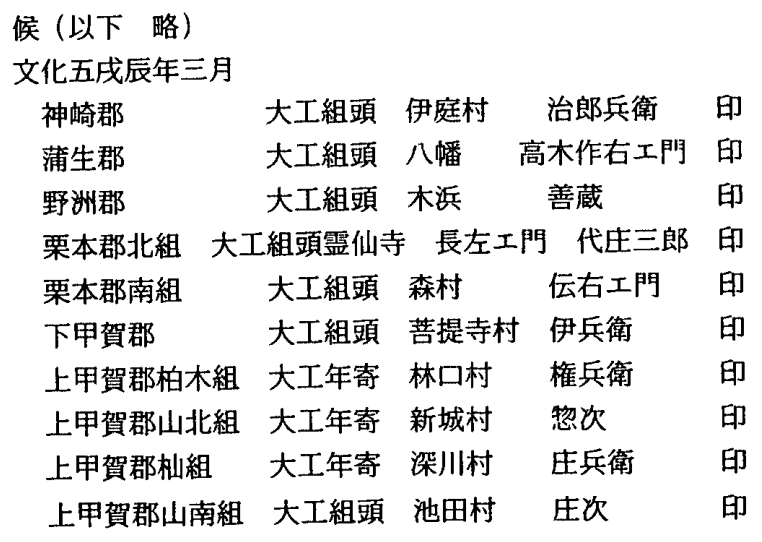

となっている。東近江五郡の大工組は 10 組となってい るが, 郡別であることには変わりなく, 郡限の紐工を申 し合わせているものである。図一2 2 文化 5 年頃の五郡 大工組の状況を示したものである。

このように東近江五郡の郡別大工組のうち, 狭域の 2 郡つまり野洲郡組と神崎郡組については郡別大工組が存 続したが, 広域の 3 郡については, 栗太郡組は北組と南 組の 2 組に分立し, 甲賀郡組は菩提寺組, 山南組, 柏木 組・山北組・杣組の 5 組に分立した。蒲生郡組治広域・ 多人数大工組であったにもかかわらず分立はせず，郡別 大工組の形を保ち続けたことがわかる。

次に 5 組の内, 野洲郡組が郡別大工組を保持しえた要 因について，甲賀郡組については，その分立の過程につ いて検討することにする。

\section{2) 野洲郡大工組存続の要因}

野洲郡大工組は幕末に至るまで郡別大工組の形を保持 した数少ない大工組であるが，その要因として組大工中 の株大工の存続とその結束力をあげることができる。

特に，明和年中株大工，平大工争論後の『申渡』に求 いては

一，弟子大工共并平大工共之内願絵図裏印持伝江候者八格别 其外之者共儀八 寺社普請受負候儀致間敷候 且又株持大 I 共之得意先江無断立入細工致候儀不相成猥成致間敷.候事 とあるように，伝来の絵図裏印を持たない弟子(弟子筋) 大工，平大工などに社寺普請の請負を禁じ，株持大工の 得意先へ無断で立ち入ることを禁じている。

また安永 6 年の『二条東御役所江差上候 大工職方出 入目安返答』においては，新規大工に対し「逆意を企私 共渡世妨仕候」，「向後親方二付添 新規我儘不仕候八渚 随分引立下絊工為致可申存念御座候」として，増加する 新規大工（弟子大工，平大工）に対して，我儘な働きを 各め，以後親方（株大工と考えられる）に付き細工する こととし, 新規大工の動きを監視する態勢を作りあげ, 株大工の仕事場所を守ることに努めたことが判る。

また，組の崩壊，分立に紫がりやすい世襲の組頭藤左 工門退去後の享保 13 年 (1728) 以降においては, 組頭 の世襲制はとらず，比較的短時間で株大工の間で組頭を 交替している。享保 13 年から慶応 3 年 (1867) の 139 


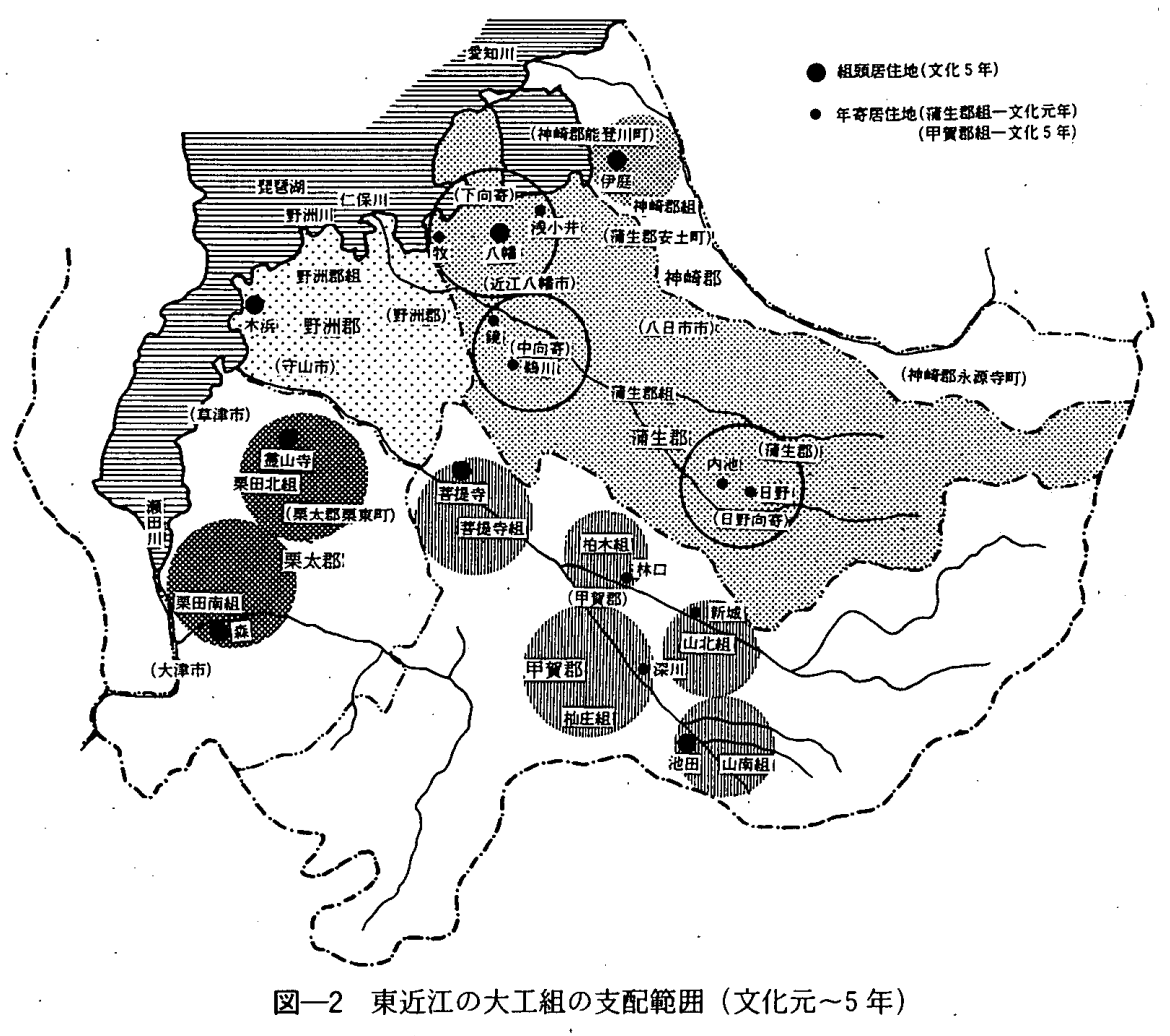

また寛延 3 年 (1750) 10 月の『乍 恐御訴訟」には「当春ヨリ一郡大 工仲間二新規二組を㹉 細工場四 組に分り候而」とあり，寛延 3 年 春には 4 人の年寄支配の 4 小組が そのまま山南組・柏木組・杣組・ 山北組の 4 組に分立していたこと が窺える。4 組の細工場所につい ては, 甲賀郡組内小組当時の場所 をそのまま引き継いだことが判 $3^{21)}$ 。甲賀郡は東部・南部に広大 な山間部を抱えており, 組大工の 仕事場所の不足が甲賀郡組の小組 間に争論を起こすことになり, 各 小組がそれまでの細工場所を守り 確立しようとしたことが 4 組への 分立を促すことになった。

しかし, 同じ（寬延 3 年）午， 10 月「作恐口上書」には「私共 より八四組之細工場組分奉願候処
年間に 13 人が交替している ${ }^{19}$ 加ら，平均 11 年毎に組頭 が代わっていることになるが，このような組頭交替制を 享保頃から採用している大工組は他には見られない。

また, 天保 12 年 (1841) 3 月の「当組与頭仮役御願受 書写」には「跡役之義一統及評儀罷在候」とあり, 次期 組頭の選出については組大工一統の評議によったことが わかる。

安政 2 年には野洲郡組の組人数も 122 人と増加するも のの, このような組運営における保守勢力である株大工 の強さと，組頭の交替制と合議制の採用それに組域の狭 さ等が, 野洲郡の郡別大工組を存続させることに繁がっ たと考えられる。

3）甲賀郡組における五組分立の過程

甲賀郡組は元禄 5 年 (1692) 当時から郡組内で四つの 小組（向寄）に分かれていた200。これは同年の「江州甲 賀郡大工組中定帳」に

無役之大工組入度と願申候引〉 四組相談之上二て古来作法 之通二組入致入可申候

とあることでも判る。甲賀郡は郡域が広域であったこと もあり, 組内を 4 小組に分け, 各小組には年奇をおき, この年寄の上に甲賀郡組の組頭佐治右エ門が存在すると 言う構成形態をとっていた。

世襲の組頭佐治右工門は享保 19 年 (1734) 7 月までは 確認できるが, 元文 2 年（1737）には退去しているらし く, 組頭の役務であった普請願書への加印も小組年寄に 代わっている。さらに元文 5 年には，甲賀郡組の代表と して組頭は欠いており (4 小組の) 年寄㥎代泉村太兵衛 がその役を勤めている。
六日否之儀可仰付旨御座候処 主水樣御死去二付延引仕 候」とあり，4組の分立は中井役所（主水）には許可さ れなかったものと推定できる。

明和 2 年（1765）の甲賀郡は西部に存在していた苦提 寺組を加えて 5 組になるが組頭は 2 人（苦提寺組が 1 人 と，先の 4 組の代表として組頭が 1 人）と言う変則的な 状況は，先のように正式な組分けが許可されなかった結 果であると考えられる。この甲賀郡組の分立がより完全 になるのは，菩提寺組を加えた 5 組の代表の 5 人が，そ の呼称が年寄であっても同列に並ぶ文化 5 年 (1808) 11 月 ${ }^{22)}$ 以降になっているからであると言えよう。

\section{小 結}

近江国の内, 東近江五郡（栗太・甲賀 - 蒲生 - 野洲 · 神崎郡）には郡別大工組が形成されたが，この郡別大工 組は中井支配六箇国のなかでも, 近江国特に東近江五郡 に特徵的にみられるものであることが知られた。これは， 中井家が江戸初期の御用作事の際に, 地理的にも便利な 東近江五郡に存在していた有力大工を大工頭として, 各 郡内大工を召集したことが郡別大工組の形成に熬がった ものと考えられる。

郡別大工組はいずれも郡域を組域とするものである が, 東近江五郡においては, 狭域の 2 郡（野洲・神崎郡） と広域の 3 郡 (栗太・甲賀・蒲生郡) が, それぞれ少人 数大工組と多人数大工組として並存していた。しかし, 各組の置かれている諸条件の相違により, 組運営方式も 同一には成りえず，各組はそれぞれに異なった変化の方 向を示すことになった。

狭域の野洲郡組と神崎郡組は世襲組頭退去後も郡別大 
工組を保ち続けるが野洲郡組では株持大工が権力を保持 し，合議制による組頭の交替・選出方式をとったことで 郡組の分立を防いでいることがわかった。

広域の栗太郡では，世襲組頭は早期に退去し，その後 栗太郡組は 2 組に分立することになった。

甲賀郡組は, 広域に居住する組大工を統括するために, 4 つの小組に分かれていた。しかし，世襲組頭の早期退 去と広大な山間部での建築需要の少なさが, · 小組間に争 論を起こさせることになり，小組は仕事場所の確立を求 めて寛延 3 年 (1750) 春に組としての分立を願い出るが 許可が得られず，郡組内の分立に止まった。甲賀郡組は この郡組内分立期を経て, 文化 5 年（1808）には正規に 5 組の向寄大工組へ分立することになったことが判る。

同じく広域の蒲生郡組では, 早くから組内に向寄を構 成していた。この向寄構成と八幡町や日野町を抱えた蒲 生郡の経済的優位性が，郡組内大工に仕事を供給し，広 域・多人数にも郡別大工組を存続させることを可能にし たと考えられるが，これについては次稿に譲ることにす る。

\section{註}

1）拙稿「河内国における大工組の变遷と支配範囲について」 日本建築学会論文報告集 318 号 昭和 57 年 8 月「河内 国古橋大工組の構成形態について」同 319 号 昭和 57 年 9 月

2）(1)黒正嚴「江州甲賀の大工仲間」経済論鋠 25-4 昭和 2 年

(2)谷口和子「近世近江国甲賀大工の研究一上甲賀郡杣組 を中心として一」滋賀県地方史研究紀要第 2 号 昭和 48 年 3 月

(3)谷 直樹「江州大工組の変容について一江州甲賀郡大 工組を中心に一」日本建築学会近畿支部研究報告集昭 和 51 年 6 月

3) 拙稿「東近江五郡の「郡組」について」日本建築学会大 会学術講演梗概集 昭和 51 年 10 月

4）表一2に示した通りで，詳しくは拙稿「東近江における 郡別大工組について」近畿大学理工学部研究報告第 21 号 昭和 60 年 9 月

他に, 野洲郡組旧川端家文書 (滋賀県中主町所藏)があり, 福田氏が報告されている

（福田敏朗 谷直樹「江戸時代における野洲郡大工組とそ の建築活動について」日本建築学会近畿支部研究報告集 昭和 61 年 6 月)

5）長香寺寄託中井家文書に含まれているもので，昭和 58 年 京都大学川上研究室で調查, 整理されている。

6）京大困書館蔵で，これについては拙稿「中井役所支配の 大工組について (大工組所在地図を中心にして)」近畿大 学理工学部研究報告第 8 号 昭和 48 年 3 月の中で紹介 している。

7）【寬永拾三年子ノ十一月 近江国中大工石高之帳】滋賀大 学史料館蔵稿本高木家文書

8) 拙稿「西近江の郡別大工組について」近畿大学理工学部 研究報告第 21 号 昭和 60 年 9 月

9）寛永期の大工頭とその組頭については，谷 直樹「寛永
期における中井家配下の大工について一「東林寺奉加帳】 を中心に一」日本建築学会近畿支部研究報告集 昭和 54 年 6 月

10）(1)「彦根御役大工之覚」(天保六年六月「御作事方肝煎勤 向帳」)「彦根市史中冊」所收 昭和 37 年 9 月彦根市役所 (2)西川幸治「元禄期彦根藩の大工について」日本建築学 会近畿支部研究報告集 昭和 31 年 6 月

(3)彦根領は, 東 · 北近江の犬上郡全域と神崎 - 蒲生 ·坂 田・愛智・浅井・伊香郡にわたって存在した。そのた め上郡に中井家支配の大工組は存在せず, 神䗁・蒲 生・坂田・愛智・浅井・伊香郡では中井家支配大工と 井伊家支配大工が混在していた。

11）寛永 13 年「江州国中大工石高之帳」により中井配下の大 工石高を見ると, 愛智郡に大工高はなく, 坂田郡は 97 石 2 斗 1 升 5 合, 浅井郡は 288 石 5 斗 5 升, 伊香淿は 212 石 9 斗 8 升 1 合と近江国の他郡に比べ, 少なかったこと がわかる。

12）文化 13 年 2 月「定畫】(「近江東浅井郡志」所収)によると, 浅井郡には大光寺組・富田組・竹生島御宮大工・高田 組・今庄組・高田向寄組の 6 組大工組がある。

13）谷 直樹「中井家六箅国大工支配の成立 - 展開過程に関 する研究」昭和 58 年 9 月

14）註 13）によると，近江国大工は，脣長 17 年の名古屋城 作事, 同 18 年の内裹作事, 元和 4 年 (1618) の江戸城内 御宮作事等の御用作事に駆りだされている。

15）蒲生郡組の高木家文書中の 2 通の中井信濃守書状は, 註: 13）によると慶長 18 年の内裏作事と元和 4 年の江戸城内 御宮作事の際の大工召集に関するもので，前者について は，「江州きも入衆」に宛て，江州より大工衆 200 人用意 して禁中御普請に出ることを要請し，後者は同じく江州 の 5 人の大工頭（兵太夫は神崎郡，又兵衛・作右衛門は 蒲生郡，三郎太夫・伊右衛門は高島郡と推定）に宛て, 江州中より「上之大工五拾人」つまり腕の優れた大工 50 人を江戸城内御宮作事に要請している。

16）註 13）によると大和国平群郡法隆寺村は中井正清の出身 地であるため, 中井家が御用作事に当たった江戸初期に おいて，法隆寺村とその周辺村居住大工を招集したため, 法隆寺村の所在する平群郡には, 密度高く大工淓が分布 することになった。

17）村上家文書文化元年【定法書」, 蒲生郡組の構成について は詳しくは次稿で述べる。

18）正徳 2 年辰 9 月の「口上之覚」(草津市史」所収）には, 栗太郡金勝庄井上村大工組頭 小右衛門，同 千右衛門 とあり，三右衛門の名はない。

19）(1)註 3）に同じ

(2)拙稿「江戸時代中・後期における六䇢国農村大工組に ついて」(川上 貢編「近世建築の生産組織と技術」昭 和 59 年 10 月所収

20)註 2)(1)，(3)に同じ

21）小山家文書午（寛延 3 年）ノ十月「年恐口上書」に，「九 ケ村八先年山北組之細工場二候所 十ケ年以来山南組源 三郎組下より参候儀八」とあり寛延 3 年以前から組向等 の細工場所はほぼ定まっていたことがわかる。

22）小山家文書文化 5 辰霜月日『前書』では柏木・杣・山北・ 山南組の代表は，いずれも年寄呼称に代っている。 (1989 年 10 月 2 日原稿受理, 1990 年 1 月 31 日採用決定 $)$ 